\title{
541 省エネ型都市交通システム「エコライド」の台車緩衝機構に関する基礎的研究
}

\author{
Basic Study on Suspension Mechanism of Energy Saving Urban Transportation System "Eco-Ride"
}

\author{
○正 山口大助（東大生研） フェロー 須田義大（東大生研） 正 安藝雅彦（東大生研） \\ 音羽勇哉（東大院） 表 久紀（泉陽興業） 金山泰雄（泉陽興業） 関口明浩（泉陽興業）
}

\begin{abstract}
Daisuke Yamaguchi, Institute of Industrial Science, The University of Tokyo, 4-6-1 Komaba, Meguro-ku, Tokyo
Yoshihiro Suda, Institute of Industrial Science, The University of Tokyo

Masahiko Aki, Institute of Industrial Science, The University of Tokyo

Yuya Otowa, School of Engineering, The University of Tokyo

Hisanori Omote, Sen-yo Kogyo Co., Ltd.

Yasuo Kanayama, Sen-yo Kogyo Co., Ltd.

Akihiro Sekiguchi, Sen-yo Kogyo Co., Ltd.
\end{abstract}

The high energy-saving new public transportation system called "Eco-Ride" has been developed to solve various traffic issues. Eco-Ride vehicle does not have on-board driving devices. The vehicle runs using potential energy with technologies of the roller coaster. The test track and the prototype vehicles were made to examine the basic performance. The secondary suspension was used as the suspension mechanism to reduce vibration transmission from the track to the vehicle body. Three kinds of secondary suspensions were installed in the newer prototype vehicle. A vehicle dynamics model was derived with consideration for the secondary suspension. Their effects of reduction of vibration transmission were confirmed by simulation. Then, the vibration acceleration was measured when prototype vehicles equipped with the secondary suspension ran on the test track. It was confirmed that vibration transmission was drastically reduced by secondary suspensions through vibration measurements.

Key Words: Public Transportation System, Roller Coaster, Secondary Suspension, Vibration Measurement

\section{A1. 緒 言}

昨今の都市交通事情や環境問題を背景に，遊園地の ジェットコースターの技術を応用した省エネ型都市交通シ ステム「エコライド」が開発された。エコライドは車両を 軌道の高いところへ引き上げ, 軌道の高低差を利用して走 行する。これまでの研究の結果から，車両が軌道の継ぎ目 を通過したときの乗り心地一の影響が検討課題に挙げられ た. そこで, 本研究では軌道から車体への上下方向の振動 の伝達を抑えて乗り心地を向上させる台車緩衝機構として 二次ばねを検討した。本稿ではシミュレーション及び試作 車両を用いた振動加速度計測の結果から, 台車緩衝機構に よる振動伝達低減効果について述べる。

\section{A2. 台車緩衝機構付き車両の振動モデル}

本研究では試作車両の車体とシャーシの間に二次ばねを 装着して振動の伝達を低隇する方法を検討する。二次ばね を装着した車両の振動モデルを図 A1 に示す，本研究では ばね定数の異なる 3 種類の二次ばねについて検討する.

図 Al の振動モデルを用いて二次ばねを装着した場合の

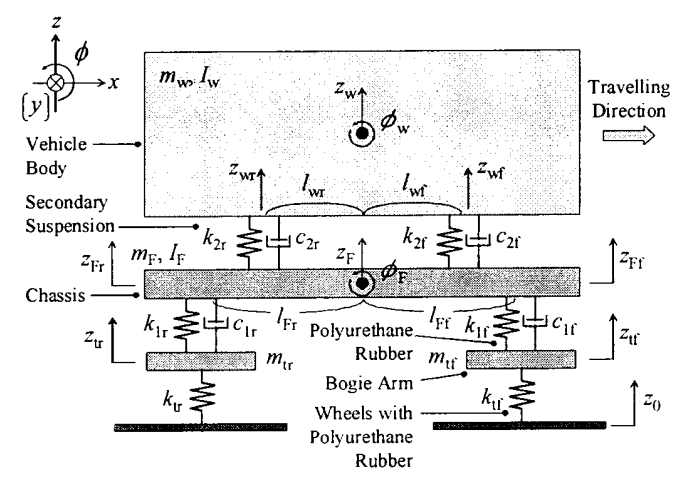

Fig.A1 Model with secondary suspension
周波数応答についてシミュレーションを行ったところ, 試 作車両の共振周波数である $13 \mathrm{~Hz}$ 及び 17 18Hz 付近の周波 数応答のゲインを抑えられることが分かり，二次ばねを装 着することで軌道から車体への上下振動の伝達を低減でき ることを確認している.

\section{A3. 振動加速度計測}

新規製作の第二次試作車両に二次ばねを実装して実験線 を走行させたときの振動加速度の計測結果から二次ばねに よる振動伝達低減効果を調べる。計測では二次ばねの種類 と車両の荷重によって六つの計測条件を設けている. 図 A2 に計測結果から得られた上下方向の振動加速度最大振幅の 二次ばねの有無による比較の一例を示す．左側が二次ばね なし，右側が二次ばねありの結果である．本結果から二次 ばねを実装することで軌道から車体への上下振動の伝達を 大幅に低減していることを確認できる。

\section{A4. 結 言}

軌道から車体一の上下方向の振動の伝達を抑えて乗り心 地を向上させる台車緩衝機構として二次ばねを検討し, シ ミュレーションと試作車両での計測を通じて振動伝達低減 効果を調べた。 その結果, 二次ばねを装着することで軌道 から車体への振動伝達を低減できることを確認した。

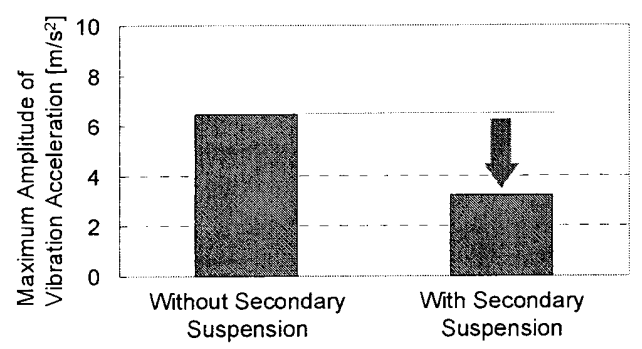

Fig.A2 Effect of reduction of vibration transmission

日本機械学会 (No.10-8〕 Dynamics and Design Conference 2010 CD-ROM論文集〔2010.9.14-18,京田辺市〕 


\section{1. 緒 言}

都市の公共交通には鉄道，地下鉄，モノレール，新交通 システム, 路面電車・LRT (Light Rail Transit : 次世代型路 面電車システム), 路線バスなどがあり, 輸送力に応じた使 い分けと機能の分担が図られている。しかしながら，特に 都市圈において，徒歩で移動するには距離が長く，新交通 システムなどを敷設するには短いというケースが多く見ら れる。このようなケースでは自家用車やバスに依存してい るのが現状である。

一方，近年，環境問題一の関心の高まりから地球温暖化 防止対策や二酸化炭素排出量削減が提唱されている. 我が 国の運輸部門における 2008 年度の二酸化炭素排出量は 2 億 3500 万トンで総排出量の約 2 割を占めており，2020 年 までに二酸化炭素排出量 $25 \%$ 削減の目標を達成するため にも運輸部門の削減は必要不可欠である.

このような都市交通事情や環境問題を背景に省エネ型都 市交通システム「エコライド」が開発された。エコライド は遊園地のジェットコースターの技術を応用した新しい概 念の公共交通システムで，車両を軌道の高いところへ引き 上げ，軌道の高低差を利用して走行する(1).

エコライドの基本性能を確認するため, 2008 年 11 月に 東京大学生産技術研究所千葉実験所に実験線を敷設し, 第 一次試作車両を製作した ${ }^{(2)}$. 筆者らは試作車両が実験線を 走行したときの前後方向 (車両進行方向) ・左右方向・上下 方向の振動加速度計測を行い，この計測結果から鉄道にお ける乗り心地の評価方法である「乗り心地係数」(3)を用い て乗り心地を解析した(4). その結果，上下方向に関しては 車両が軌道の継ぎ目を通過したときの乗り心地への影響が 検討課題に挙げられた.

そこで，本研究では軌道から車体への上下方向振動の伝 達を抑えて乗り心地を向上させる台車緩衝機構について検 討した. 具体的には, 二次ばねによる台車緩衝機構として, 初めに二次ばねを含む車両の振動モデルを導出し, シミュ レーションにより振動伝達低減効果を検討した。次に，新 規製作した第二次試作車両に二次ばねを実装して走行実験 を行い，そのとき計測した振動加速度の結果から二次ばね による振動伝達低減効果を検討した．本稿ではシミュレー ション及び実験を通じての検討結果について述べる.

\section{2. 省エネ型都市交通システム「エコライド」}

エコライドはジェットコースターの技術を応用した新し い概念の公共交通システムで，位置エネルギ創出装置に よって車両を軌道の高いところへ引き上げ，軌道の高低差 を利用して走行する，車両側に動力を持たず，軦道側に駆 動装置及び制動装置を設けており，車両軽量化による省エ ネ走行の実現と建設コストの低減を特徽としている( ${ }^{(2)}$.

エコライドの特色である位置エネルギを活用するための 路線構成の一例を図 1 亿示す. 車両が C 駅から A 駅までと A 駅から B 駅まで移動する際は位置エネルギにより走行す る. B 駅から C 駅一移動する際は地上側に設置された位置 エネルギ創出装置により車両を引き上げる.

エコライドの軌道及び台車構造はジェットコースターで 実績のある図 2 に示す構造を踏襲している. 軌道は左右 2 本の円形鋼管のレール, 主析, 避難路で主に構成される. 台車は主車輪, 側車輪 (ガイド車輪), 浮上り防止車輪で構 成され，コの字型でレールを挟み込む 3 方向支持・案内方 式となっている。この構造は脱線が発生しにくく，安全性 が高い利点を有する．車輪はウレタンゴム製である．
車両走行のための駆動装置及び制動装置は軌道側に設け られ，車両側には搭載されない。よって，車両の軽量化が 可能となり，走行エネルギの低減を図ることができる、車 両が軽量なため, 軌道を構成する構造体も軽量で簡素な構 造に寸ることができる、これにより製造段階で省資材と輸 送コスト低減を図ることができる，実用時は一定の長さの 軌道構造体が工場にて複数造られ，現地においてこれらを つなげる工法で軌道が敷設される。軌道構造体同上は溶接 によってつなぎ合わせられるが, 台車の車輪が溶接された 継ぎ目を通過するときに振動が発生し，車体への振動の伝 播が予想される。

\section{3. 実験線及び第一次試作車両}

エコライドの基本性能を確認するため, 2008 年 11 月に 東京大学生産技術研究所千葉実験所に実験線を敷設し, 第 一次試作車両を製作した。実験線と第一次試作車両を図 3 に示す。実験線は全長 $99.8 \mathrm{~m}$, 始点と終点の高低差 $2.88 \mathrm{~m}$ となっている. 実験線には実用時を想定した曲線半径 $15 \mathrm{~m}$ の急曲線や傾斜 8 度の急勾配を設けている. 急勾配通過後 の走行速度は約 $25 \mathrm{~km} / \mathrm{h}$ である. 軌道幅は $1500 \mathrm{~mm}$ となっ ている. 実験線の概略を図 4 に示す.

第一次試作車両は主に台車の試験·評価を目的に造られ, 車体寸法は幅 $2200 \times$ 高さ $2200 \times$ 長さ $4750 \mathrm{~mm}$ である ${ }^{(2)}$. 台 車にウレタンゴムが挿入されているが，これはレールの表 面粗さなどの軌道狂いを吸収するためのもので，軌道から 車体への上下方向振動の伝達の低減にはほとんど寄与しな い. 筆者らは試験車両が実験線を走行したときの前後・左 右・上下方向の振動加速度計測を行い, その結果, 上下方 向の振動加速度振幅が大きく，車雨が軌道の継ぎ目を通過 したときの乗り心地一の影響を検討課題に挙げている(4). これは軌道から車体への振動の伝播が大きく, 低減する必 要があることを指している.

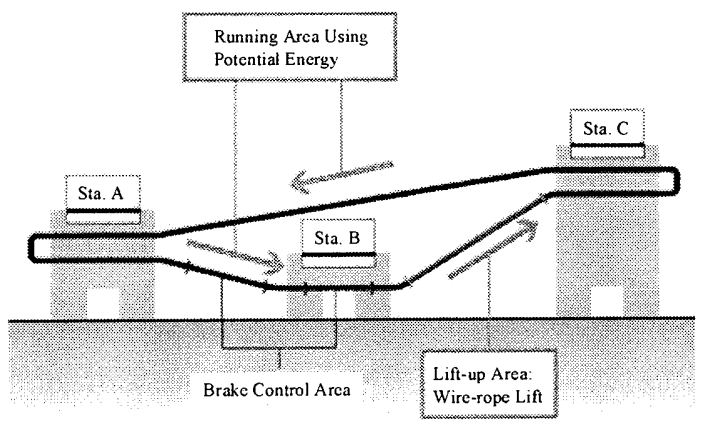

Fig.1 Schematic diagram of Eco-Ride route

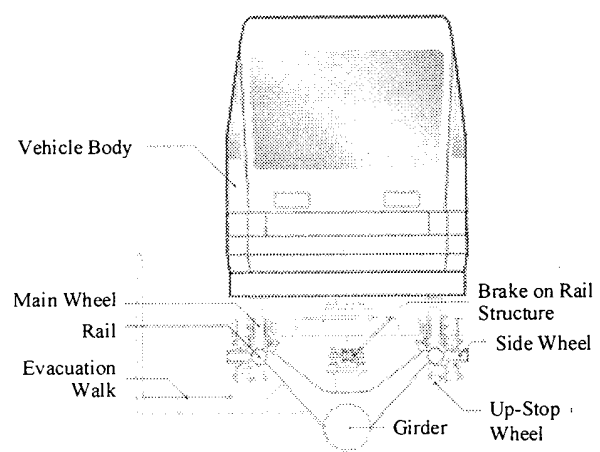

Fig.2 Schematic view of Eco-Ride profile 


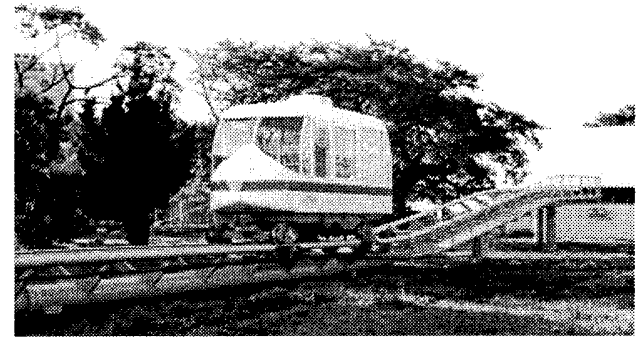

Fig.3 Test track and first prototype vehicle

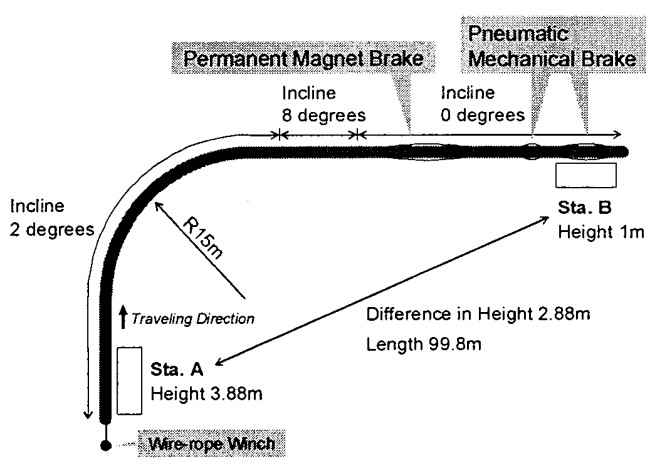

Fig.4 Schematic view of test track

\section{4. 台車緩衝機構の検討}

4-1 第一次試作車両のモデリング 軌道から車体への 上下方向の振動の伝達を抑えて乗り心地を向上させる台車 緩衝機構についてシミュレーションで検討を行うため，初 めに第一次試作車両の振動モデルを導出する.

第一次試作車両は車体，シャーシ，ボギーアーム，車輪 で大きく構成されている．シャーシは車体と台車を接続す る部材で，車体とシャーシは固定されていることから，こ こでは車体とシャーシを一体と見なす，本節では車体と シャーシを一体にして車体と呼ぶことにする．前述のよう に，台車には軌道狂いなどを吸収するウレタンゴムが挿入 されているが，構造上は台車とシャーシの間に挟まれる形 となっており，車両の振動モデルでは台車の構成要素の一 つであるボギーアームとシャーシの間にウレタンゴムが備 わる形で表される，ボギーアームは左右両側の車輪を結合 するための梁である. 一方, ウレタンゴム車輪はレールに 接地し, ボギーアームに固定された輪軸に取り付けられて いることから，ウレタンゴム車輪はレールとボギーアーム の間に挟まれる形で表される。図 5 に第一次試作車両の振 動モデルを示す.この図において $x$ 軸方向を前後方向（車 両進行方向), $\mathrm{y}$ 軸方向を左右方向, $z$ 軸方向を上下方向と する.ここでは進行方向前側の車輪が軌道の継ぎ目を通過 したときの軌道の上下変位を入力としている. 図 5 より上

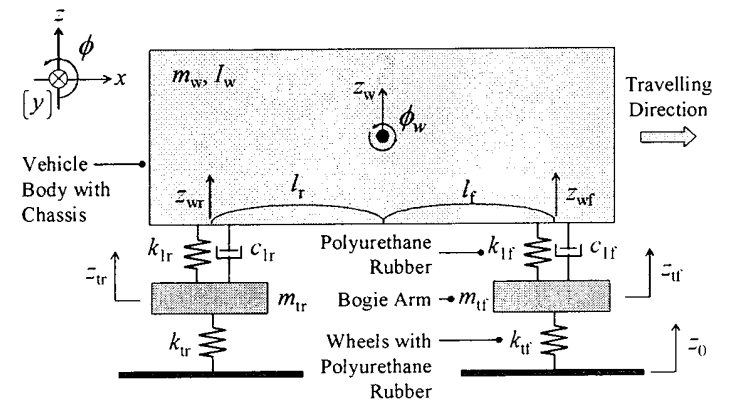

Fig.5 Model of first prototype vehicle
下方向に関する運動方程式から次式が導かれる。

$$
\begin{aligned}
& \dot{z}=\left[\begin{array}{cc}
-M^{-1} C & -M^{-1} K \\
I & 0
\end{array}\right] z+\left[\begin{array}{c}
M^{-1} k_{0} \\
0
\end{array}\right] z_{0} \\
& y=\left[\begin{array}{llllllll}
0 & 0 & 0 & 0 & 1 & 0 & 0 & 0
\end{array}\right] z \\
& z=\left\{\begin{array}{llllllll}
\dot{z}_{w} & \dot{\phi}_{w} & \dot{z}_{t f} & \dot{z}_{t r} & z_{w} & \phi_{w} & z_{t f} & z_{t r}
\end{array}\right\}^{T}
\end{aligned}
$$$$
\boldsymbol{M}=\left[\begin{array}{cccc}
m_{w} & 0 & 0 & 0 \\
0 & I_{w} & 0 & 0 \\
0 & 0 & m_{t f} & 0 \\
0 & 0 & 0 & m_{t r}
\end{array}\right]
$$$$
\boldsymbol{C}=\left[\begin{array}{cccc}
c_{1 f}+c_{1 r} & c_{1 f} l_{f}+c_{1 r} l_{r} & -c_{1 f} & -c_{1 r} \\
c_{1 f} l_{f}-c_{1 r} l_{r} & c_{1 f} l_{f}^{2}+c_{1 r} l_{r}^{2} & -c_{1 f} l_{f} & c_{1 r} l_{r} \\
-c_{1 f} & -c_{1 f} l_{f} & c_{1 f} & 0 \\
c_{1 r} & c_{1 r} l_{r} & 0 & c_{1 r}
\end{array}\right]
$$$$
\boldsymbol{K}=\left[\begin{array}{cccc}
k_{1 f}+k_{1 r} & k_{1 f} l_{f}-k_{1 r} l_{r} & -k_{1 f} & -k_{1 r} \\
k_{1 f} l_{f}-k_{1 r} l_{r} & k_{1 f} l_{f}^{2}+k_{1} l_{r}^{2} & -k_{1 f} l_{f} & k_{1 r} l_{r} \\
-k_{1 f} & -k_{1 f} l_{f} & k_{t f}+k_{1 r} & 0 \\
-k_{1 r} & k_{1 r} l_{r} & 0 & k_{t r}+k_{1 r}
\end{array}\right]
$$$$
\boldsymbol{k}_{0}=\left\{\begin{array}{llll}
0 & 0 & k_{t f} & 0
\end{array}\right\}
$$

ここで,

$\boldsymbol{I}:$ 単位行列 $(4 \times 4)$

$m_{w}[\mathrm{~kg}]$ : 車体質量

$I_{w}\left[\mathrm{kgm}^{2}\right]$ : 車体の $y$ 軸回りの慣性モーメント

$z_{w f}, z_{w r}[\mathrm{~m}]:$ ウレタンゴムの車体取付点の上下変位

$l_{f}, l_{r}[\mathrm{~m}]$ : 車体重心からウレタンゴム取付点までの距離 $k_{1 f}, k_{1 r}[\mathrm{~N} / \mathrm{m}]$ : ウレタンゴムばね定数

$c_{1 f}, c_{1 r}[\mathrm{~kg} / \mathrm{s}]$ : ウレタンゴム減衰定数

$z_{t f}, z_{t r}[\mathrm{~m}]:$ ボギーアーム上下変位

$m_{t f}, m_{t r}[\mathrm{~kg}]:$ ボギーアーム質量

$k_{t}, k_{t r}[\mathrm{~N} / \mathrm{m}]$ : ウレタンゴム車輪ばね定数

$z_{0}[\mathrm{~m}]:$ 軌道上下変位

なお，添え字の $f と r$ はそれぞれ進行方向前側及び後ろ 側を表す。また，一つの台車にウレタンゴム車輪，ウレタ ンゴムともに四つあることから， $k_{1} ， c_{1}, k_{t}$ はそれぞれ四つ を合成した値としている.

ここで，第一次試作車両が実験線を走行したときの振動 加速度計測の結果から求めた上下方向振動加速度のパワー スペクトルの一例を図 6 に示す。この結果から $18 \mathrm{~Hz}$ 付近 とやや小さいものの $13 \mathrm{~Hz}$ 付近にピークが現れていること が分かる。この值付近が第一次試作車両の共振周波数であ ると考えられる.

一方, 式(1),(2),(3)に車体重量などの数値を代入して得ら れた軌道から車体への振動伝達に関する周波数応答のシ ミュレーション結果を図 7 に示す。この結果より $13.3 \mathrm{~Hz}$ 及び $16.9 \mathrm{~Hz}$ 付近に共振ピークが現れていることが分かる. 図 6 と図 7 より，值はやや異なるものの両者で共振周波数 がほぼ一致していることから，本研究ではこの二つの共振 周波数付近を対象に振動の伝達を抑える台車緩衝機構を検

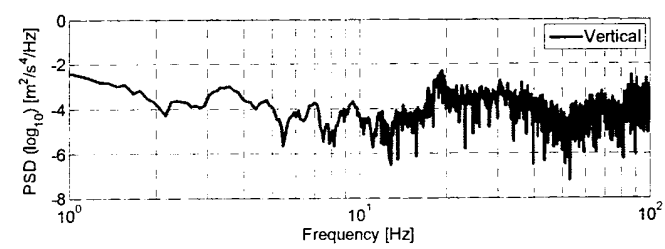

Fig.6 Measurement result of vibration response 


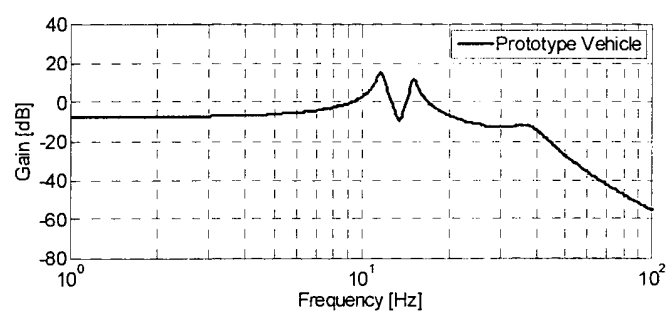

Fig.7 Simulation result of vibration response

討する.なお，シミュレーション結果では $38.7 \mathrm{~Hz}$ 付近にも 共振ピークが現れている。 これは第一次試作車両では $l_{f}$ と $l_{r}$ が異なる寸法になっており，ウレタンゴムの取付位置が 非対称であるために現れたものと考えられる.

4.2 台車緩衝機構付き車両のモデリング 軌道から車 体への振動の伝達を抑えるため，本研究では二次ばねによ る台車緩衝機構を検討する。一般的な鉄道車両では車輪と 台車枠の間に一次ばね，台車（台車枠）と車体の間に二次 ばねを装着することで軌道から車体へ伝わる振動を低減さ せ，乗り心地を向上させている ${ }^{(3)}$.

本研究では試作車両の車体とシャーシの間に二次ばねを 装着したときの振動伝達低減効果を検討寸る. 図 8 に二次 ばねを装着した車両の振動モデルを示す。このモデルより 車両の上下方向に関する運動方程式から次式が導かれる.

$$
\begin{aligned}
& \dot{\boldsymbol{z}}=\left[\begin{array}{cc}
-\boldsymbol{M}^{-1} \boldsymbol{C} & -\boldsymbol{M}^{-1} \boldsymbol{K} \\
\boldsymbol{I} & \boldsymbol{0}
\end{array}\right] z+\left[\begin{array}{c}
\boldsymbol{M}^{-1} \boldsymbol{k}_{0} \\
\boldsymbol{0}
\end{array}\right] z_{0} \\
& y=\left[\begin{array}{llllllllllll}
0 & 0 & 0 & 0 & 0 & 0 & 1 & 0 & 0 & 0 & 0 & 0
\end{array}\right] z \\
& z=\left\{\begin{array}{llllllllllll}
\dot{z}_{w} & \dot{\phi}_{w} & \dot{z}_{F} & \dot{\phi}_{F} & \dot{z}_{t f} & \dot{z}_{t f} & z_{w} & \phi_{w} & z_{F} & \phi_{F} & z_{t f} & z_{t r}
\end{array}\right\}^{T}
\end{aligned}
$$$$
\boldsymbol{M}=\left[\begin{array}{cccccc}
m_{w} & 0 & 0 & 0 & 0 & 0 \\
0 & I_{w} & 0 & 0 & 0 & 0 \\
0 & 0 & m_{F} & 0 & 0 & 0 \\
0 & 0 & 0 & I_{F} & 0 & 0 \\
0 & 0 & 0 & 0 & m_{t f} & 0 \\
0 & 0 & 0 & 0 & 0 & m_{t r}
\end{array}\right]
$$$$
\boldsymbol{C}=\left[\begin{array}{cccccc}
C_{11} & C_{12} & C_{13} & C_{14} & 0 & 0 \\
C_{21} & C_{22} & C_{23} & C_{24} & 0 & 0 \\
C_{31} & C_{32} & C_{33} & C_{34} & C_{35} & C_{36} \\
C_{41} & C_{42} & C_{43} & C_{44} & C_{45} & C_{46} \\
0 & 0 & C_{53} & C_{54} & C_{55} & 0 \\
0 & 0 & C_{63} & C_{64} & 0 & C_{66}
\end{array}\right]
$$$$
\boldsymbol{k}_{0}=\left\{\begin{array}{llllll}
0 & 0 & 0 & 0 & k_{t f} & 0
\end{array}\right\}
$$

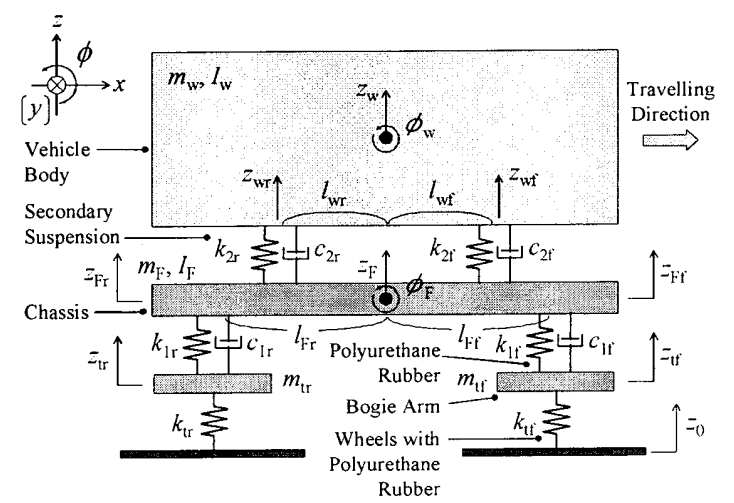

Fig.8 Model with secondary suspension
$\boldsymbol{K}=\left[\begin{array}{cccccc}K_{11} & K_{12} & K_{13} & K_{14} & 0 & 0 \\ K_{21} & K_{22} & K_{23} & K_{24} & 0 & 0 \\ K_{31} & K_{32} & K_{33} & K_{34} & K_{35} & K_{36} \\ K_{41} & K_{42} & K_{43} & K_{44} & K_{45} & K_{46} \\ 0 & 0 & K_{53} & K_{54} & K_{55} & 0 \\ 0 & 0 & K_{63} & K_{64} & 0 & K_{66}\end{array}\right]$

$C_{13}=c_{2 f}+c_{2 r} \quad C_{12}=c_{2 f} l_{w f}-c_{2 r} l_{w r} \quad C_{13}=-c_{2 f}-c_{2 r}$

$C_{14}=-c_{2 f} l_{F f}+c_{2 r} l_{F r} \quad C_{21}=c_{2 f} l_{w f}-c_{2 r} l_{w r} \quad C_{22}=c_{2 f} l_{w f}{ }^{2}+c_{2 r} l_{w r}{ }^{2}$

$C_{23}=-c_{2 f} l_{w f}+c_{2 r} l_{w r} \quad C_{24}=-c_{2 f} l_{F f} l_{w f}-c_{2 r} l_{F r} l_{w r} \quad C_{31}=-c_{2 f}-c_{2 r}$

$C_{32}=-c_{2 f} l_{w f}+c_{2 r} l_{w r} \quad C_{33}=c_{1 f}+c_{1 r}+c_{2 f}+c_{2 r}$

$C_{34}=c_{1 f} l_{F f}-c_{1 r} l_{F r}+c_{2 f} l_{F f}-c_{2 r} l_{F r r} \quad C_{35}=-c_{1 f} \quad C_{36}=-c_{1 r}$

$C_{41}=-c_{2 f} l_{w f}+c_{2 r} l_{w r} \quad C_{42}=-c_{2 f} l_{w f}{ }^{2}-c_{2 r} l_{w r}{ }^{2}$

$C_{43}=c_{1 f} l_{F f}-c_{1 r} l_{F r}+c_{2 f} l_{w f}-c_{2 r} l_{w r}$

$C_{44}=c_{1 f} l_{F f}{ }^{2}+c_{1 r} l_{F r}^{2}+c_{2 f} l_{F f} l_{w f}+c_{2 r} l_{F r} l_{w r} \quad C_{4 j}=-c_{1 f} l_{F f}$

$C_{46}==c_{1 r} l_{F r} \quad C_{53}=-c_{1 f} \quad C_{54}=-c_{1 f} l_{F f} \quad C_{55}=c_{1 f}$

$C_{63}=-c_{1 r} \quad C_{64}=c_{1 r} l_{F r} \quad C_{66}=c_{1 r}$

$K_{11}=k_{2 f}+k_{2 r} \quad K_{12}=k_{2 f} l_{w f}-k_{2 r} l_{w r} \quad K_{13}=-k_{2 f}-k_{2 r}$

$K_{14}=-k_{2 f} l_{F f}+k_{2 r} l_{F r} \quad K_{21}=k_{2 f} l_{w f}-k_{2 r} l_{w r} \quad K_{22}=k_{2 f} l_{w f}{ }^{2}+k_{2 r} l_{w r}{ }^{2}$

$K_{23}=-k_{2 f} l_{w f}+k_{2 r} l_{w r} \quad K_{24}=-k_{2 f} l_{F f} l_{w f}-k_{2 r} l_{F r} l_{w r} \quad K_{31}=-k_{2 f}-k_{2 r}$

$K_{32}=-k_{2 f} l_{w f}+k_{2 r} l_{w r} \quad K_{33}=k_{1 f}+k_{1 r}+k_{2 f}+k_{2 r}$

$K_{34}=k_{1 f} l_{F f}-k_{1 r} l_{F r}+k_{2 f} l_{F f}-k_{2 r} l_{F f} \quad K_{35}=-k_{1 f} \quad K_{35}=-k_{1 r}$

$K_{4 l}=-k_{2 f} l_{w f}+k_{2 r} l_{w r} \quad K_{42}=-k_{2 f} l_{w f}^{2}-k_{2 r} l_{w r}{ }^{2}$

$K_{43}=k_{1 f} l_{F f}-k_{1 r} l_{F r}+k_{2 f} l_{w f}-k_{2 r} l_{w r}$

$K_{44}=k_{1 f} l_{F f}^{2}+k_{1 r} l_{F r}^{2}+k_{2 f} l_{F f} l_{w f}+k_{2 r} l_{F r} l_{w r} \quad K_{45}=-k_{1 f} l_{F f}$

$K_{46}=k_{1 r} l_{F r} \quad K_{53}=-k_{1 f} \quad K_{54}=-k_{1 f} l_{F f} \quad K_{55}=k_{t f}+k_{1 f}$

$K_{63}=-k_{1 r} \quad K_{64}=k_{1 r} l_{F r} \quad K_{66}=k_{1 r}+k_{1 r}$

ここで,

$I:$ 単位行列 $(6 \times 6)$

$m_{w}[\mathrm{~kg}]$ : 車体質量

$I_{w}\left[\mathrm{kgm}^{2}\right]$ : 車体の $y$ 軸回りの慣性モーメント

$z_{w f}, z_{w r}[\mathrm{~m}]$ : 二次ばねの車体取付点の上下変位

$l_{w f}, l_{w r}[\mathrm{~m}]:$ 車体重心から二次ば权取付点までの距離

$k_{2 f}, k_{2 r}[\mathrm{~N} / \mathrm{m}]:$ 二次ばねのばね定数

$c_{2 f}, c_{2 r}[\mathrm{~kg} / \mathrm{s}]$ : 二次ばねの減衰定数

$m_{F}[\mathrm{~kg}]$ : シャーシ質量

$I_{F}\left[\mathrm{kgm}^{2}\right]$ : シャーシの $y$ 軸回りの慣性モーメント

$z_{F f}, z_{F r}[\mathrm{~m}]:$ ウレタンゴムのシャーシ取付点の上下変位

$l_{F f}, l_{F r}[\mathrm{~m}]:$ :ャーシ重心からウレタンゴム取付点までの

距離

$k_{\mathrm{l},}, k_{1 r}[\mathrm{~N} / \mathrm{m}]:$ ウレタンゴムばね定数

$c_{1 f}, c_{1 r}[\mathrm{~kg} / \mathrm{s}]:$ ウレタンゴム減衰定数

$z_{t f}, z_{t r}[\mathrm{~m}]:$ ボギーアーム上下変位

$m_{t f}, m_{t r}[\mathrm{~kg}]:$ ボギーアーム質量

$k_{t f}, k_{t r}[\mathrm{~N} / \mathrm{m}]$ : ウレタンゴム車輪ばね定数

$z_{0}[\mathrm{~m}]$ : 軌道上下変位

なお，添え字の $f$ と はそれぞれ進行方向前側及び後ろ 側を表す．先と同様に $k_{1}, c_{1}, k_{1}$ はそれぞれ四つを合成し た值としている。また二次ば孙は進行方向前側, 後乃側と もに左右で一つずつあり，前側と後ろ側で各々計二つであ ることから， $k_{2} ， c_{2}$ は二つを合成した值としている.

$4 \cdot 3$ 台車緩衝機構軌道から車体への上下方向の振動 の伝達を低減するため，二次ば称を車体とシャーシの間に 装着することで振動の伝達を低減可能な周波数領域を広げ ることを考える。そのために，(1)ばね定数の小さな二次ば ねによって低次の固有振動数を小さくする，(2)共振周波数 付近の振動伝達率（ゲイン）を抑える，(3)低周波領域のゲ 
インを低くする，の三点を踏まえる。一方，実用時には輸 送状況によって乗車人員が逐次変化するため，乗員を含む 車体重量が大きく変化し, 振動伝達特性も変化するものと 思われる.この場合はアクティブち式の緩衝機構が有効で あるが，構造が複雑で重量が大きくなり，走行エネルギの ロスが大きくなってエコライドの利点に相反してしまうた め, 本研究ではパッシブ方式の機構を対象とする.

二次ばねを装着する車両を新たに設計し，車体寸法など から乗員が皆無の空車状態の荷重を $920 \mathrm{~kg}, 12$ 名定員とし たときの満員状態の荷重を $1700 \mathrm{~kg}$ とする. 許容荷重などを 考慮に入れて検討した結果, 本研究では 3 種類の二次ばね の振動伝達低減効果を調べる。ここでは二次ばねをタイプ $\mathrm{A}$, タイプ $\mathrm{B}$, タイプ $\mathrm{C}$ と呼ぶ. ばね定数は $\mathrm{A} \rightarrow \mathrm{B} \rightarrow \mathrm{C}$ の順 に大きい.

図 8 の振動モデルを用いて 3 種類の二次ばねを装着した ときの周波数応答のシミュレーション結果を図 9 に示す. 図 9(a)は二次ばねを装着していない第一次試作車両（図 7 の再掲)，(b)はタイプ A, (c)はタイプ B，(d)はタイプ Cの 場合で，ここではゲインの結果を示している．各グラフと も横軸は周波数, 縦軸はゲインである. 本結果より 3 種類 ともに振動の伝達を低減する周波数領域が広くなっており 第一次試作車両の共振周波数である $13 \mathrm{~Hz}$ と $17 \sim 18 \mathrm{~Hz}$ 付近 のダインを抑えられていることが分かる. 3 種類のうちで タイプ A が伝達を最も低く抑えられている.

\section{5. 台車緩衝機構の実装と振動加速度計測}

5.1 第二次試作車両台車緩衝機構として二次ばねを 実装した図 10 に示す第二次試作車両を新たに製作し，第一 次試作車両の前に連結させた状態で走行実験を行っている。 第二次試作車両の車体は第一次試作車両と比べて, 快適性 と乗降容易性を損なわず，かつ省エネ効果を考慮の上で小 型化している(5). 図 11 に第二次試作車両への二次ばねの実 装の様子を示す。二次ばねは車体とシャーシの間の 4 か所 に実装される.

$5 \cdot 2$ 振動加速度計測 二次ばねを実装した第二次試作 車両が実験線を走行したときの振動加速度計測の結果から 振動伝達低減効果を検討する。

加速度計測では両試作車両の車内及びボギーアームの進 行方向前側右車輪そばに加速度センサを取り付ける。これ らのセンサでの計測によって軌道から車体への振動伝達の 低減度合いを調べることができる．実際にはすべての車輪 に振動が加わって車両へ伝播するが，ここでは走行時に最 初に軌道の継ぎ目を通過する進行方向前側右車輪の振動加 速度を計測する.

本研究では二次ばねの種類及び車体の荷重状態によって 以下の六つの条件に分けて計測する.

・条件 I：二次ばねタイプ A 実装, 両車両とも無負荷

・条件 II : タイプ A 実装, 両車両とも $780 \mathrm{~kg}$ 負荷

・条件 III：タイプ B 実装, 両車両とも無負荷

・条件 IV：タイプ B 実装, 両車両とも $780 \mathrm{~kg}$ 負荷

・条件 V : タイプ C 実装, 両車両とも無負荷

・条件 VI : タイプ C 実装, 両車両とも $780 \mathrm{~kg}$ 負荷

条件 I・III・Vの無負荷は空車状態, 条件 II・IV・VI は 一人当たりの体重を $65 \mathrm{~kg}$ とした定員 12 名乗車の状態（以 下，乗車状態）を想定しており，780kg の負荷はウェイト を積載することで模擬している.

5.3 加速度計測結果図 12 に上記の六つの計測条件に 招ける上下方向の振動加速度の計測結果を示す．各条件と もに上段のグラフは第一次試作車両，下段のグラフは第二

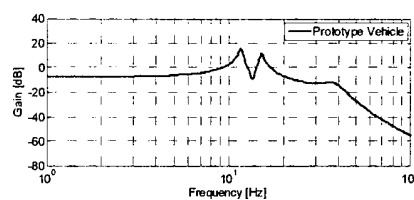

(a) Without secondary suspension

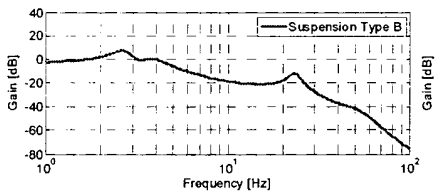

(c) Type B

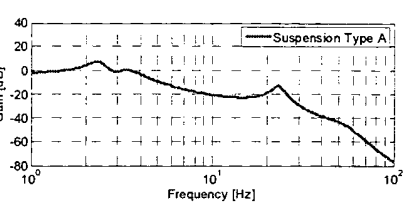

(b) Type A

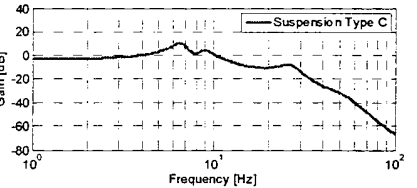

(d) Type C
Fig.9 Simulation results of vibration response

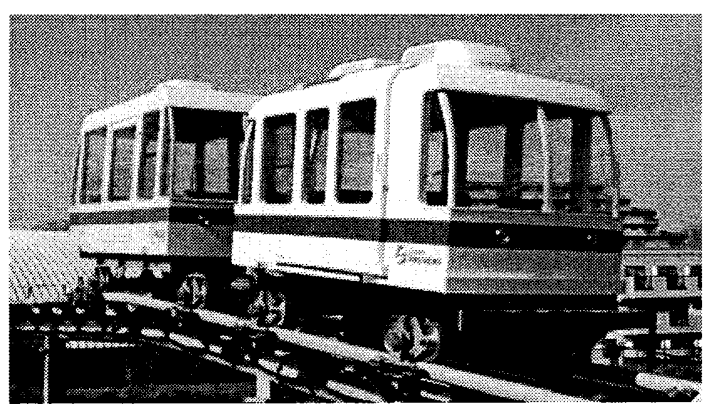

Fig.10 Second prototype vehicle

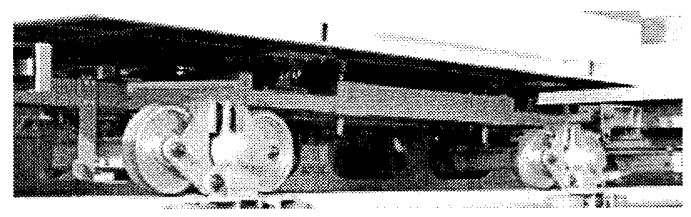

Fig.11 Installation of secondary suspension

次試作車両の車内振動加速度の結果である. 各グラフとも 横軸を時間, 縦軸を振動加速度としている. 本結果より, 空車状態の第一次試作車両の振動加速度が乗車状態のとき と比べて明らかに大きいことが分かる。これは空車状態で は車体重量が軽く, 第一次試作車両には二次ばねが装着さ れていないため, 軌道からの振動が車体に伝わりやすく, その影響が現れたものと考えられる. 乗車状態では車体重 量が増えるため，振動加速度は小さいと考えられる．

また，いずれの結果からも二次ばねを装着することに よって車体に働く上下方向の振動を低減できていることが 分かる. 空車状態と乗車状態で振動加速度の大きさに違い が見られるものの，二次ばねによる振動伝達低減効果を確 認することができる. 3 種類の二次ばねの中ではタイプ A が振動を最も低減できているといえる.

次に, ボギーアームの進行方向前側右車輪そばの振動加 速度と車内の振動加速度から周波数応答を求める.これに よって軌道から車体への振動伝達の様子及び二次ばねによ る伝達低減効果を調べることができる．ボギーアームの進 行方向前側右車輪そばの振動加速度を軌道から車輪に加わ る上下方向の振動と見なして入力，車体に働く上下方向の 振動加速度を出力とする. 図 13 に周波数応答のゲインの結 果を示す. 各グラフとも横軸は周波数, 縦軸はゲインで, 破線（青）が第一次試作車両, 実線 (赤) が第二次試作車 両である. 本結果から, 空車, 乗車状態ともに対象とする $13 \mathrm{~Hz}$ 及び 17 18Hz 付近のゲインを抑えられていることが 分かる.よって, 二次ばねの装着により軌道から車体への 


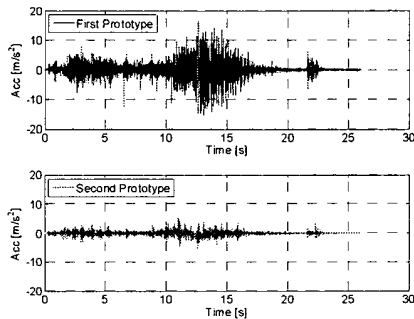

(a) Condition I

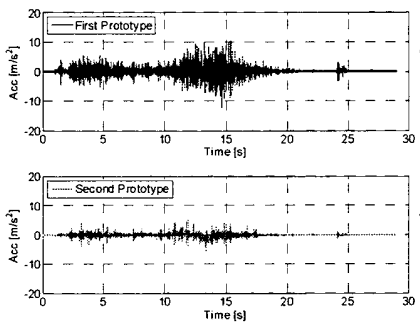

(c) Condition III

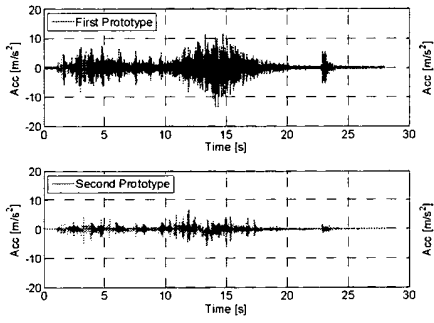

(e) Condition V

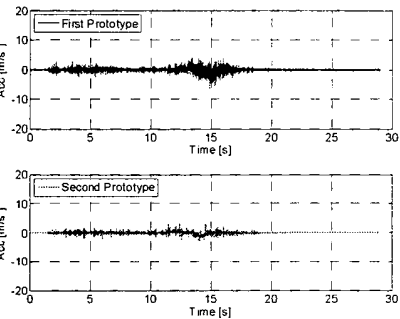

(b) Condition II

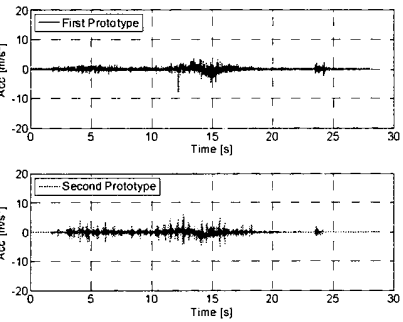

(d) Condition IV

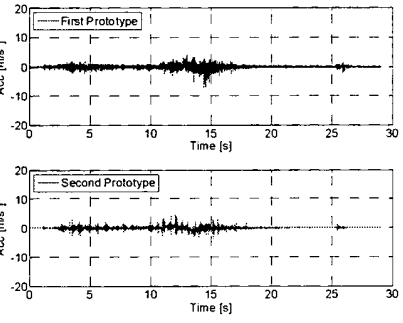

(f) Condition VI

Fig. 12 Measurement results of vibration acceleration

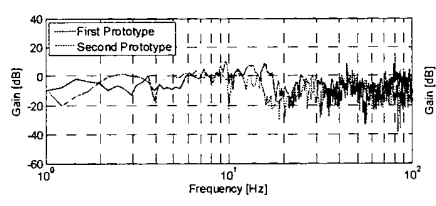

(a) Condition I

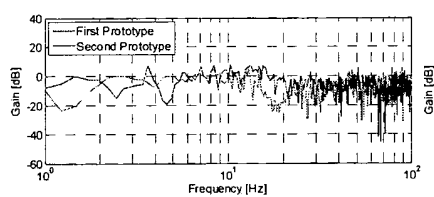

(c) Condition III

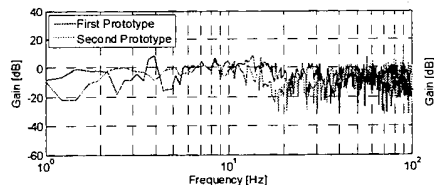

(e) Condition V

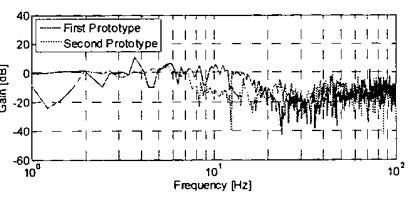

(b) Condition II

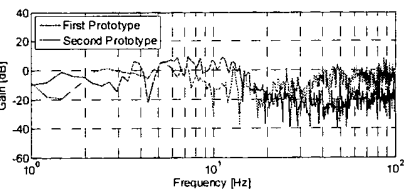

(d) Condition IV

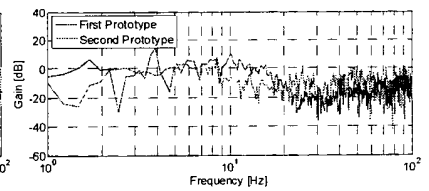

(f) Condition VI

Fig. 13 Measurement results of vibration response

振動の伝達を低減できているといえる.

3 種類の二次ばねの結果を比較すると, タイプ A が最も 低減できており, 次にタイプ $\mathrm{B}$, タイプ $\mathrm{C}$ の順で低減でき ている。これはばね定数の小さな順に一致しており， $4 \cdot 3$ 節で述べたように，ばね定数の小さな二次ばねを装着する ことで良好な振動伝達低減効果を得られるといえる。

図 14 に振動加速度最大振幅の二次ばねの有無による比 較の一例を示す。左側が二次ばねなし，右側が二次ばねあ りの結果である。本結果から二次ばねを実装することで軌 道から車体への上下振動の伝達を大幅に低減できているこ とを確認できる.

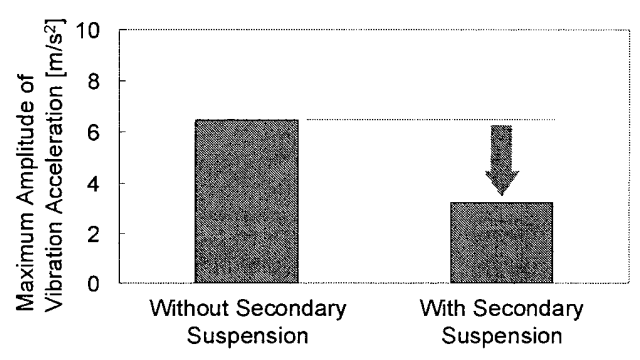

Fig.14 Effect of reduction of vibration transmission

\section{6. 結 言}

本研究では省エネ型都市交通システム「エコライド」に おいて, 軌道から車体への上下方向の振動の伝達を抑えて 乗り心地を向上させる台車緩衝機構についてシミュレー ションと試作車両を用いた実験を通じて検討した．結論を 以下にまとめる.

(1) 第一次試作車両を対象にモデリングを行い，車体の共 振周波数についてシミュレーション結果と計測結果を 比較し，両者がほぼ一致することを確認した。

(2) 軌道から車体への上下振動の伝達を低減する台車緩衝 機構として二次ばねを検討し，二次ばねを装着した車 両のモデリングを行った.

(3) ばね定数の異なる 3 種類の二次ばねを対象に, 上記(2) で得たモデルを用いて振動伝達低減効果に関するシ ミュレーションを行い, その効果を確認した.

(4) 第二次試作車両に二次ばねを実装し，二次ばねの種類 及び車体の荷重状態によって六つの条件に分けて振動 加速度を計測した。

（5）上下方向の振動加速度の計測結果を示し，二次ばねを 装着することで軌道から車体への振動伝達を低減でき ることと，二次ばねの違いによる振動伝達低減効果の 違いを確認した。

\section{謝 辞}

本研究は経済産業省「低炭素社会に向けた技術発掘・社 会システム実証モデル事業」の「ITS 中量公共交通機関「エ コライド」の開発による低炭素化地域交通モデルの実証研 究」として進められました. 関係各位に深謝申し上げます.

\section{参考文献}

（1）須田義大・表 久紀，省エネ型都市交通システム「エコ ライド」, 日本機械学会誌 2010 年 3 月号, Vol.113, No.1096, (2010), 203.

(2) 関口明浩 - 金山泰雄 - 表 久紀 - 須田義大 - 山口大助, 省エネ型都市交通システム「エコライド」の開発，第 11 回運動と振動の制御シンポジウム講演論文集, (2009), 370-374.

(3) 日本機械学会, 鉄道車両のダイナミクスー最新の台車 テクノロジーー, 電気車研究会, (1994)

(4) 山口大助 - 須田義大・表 久紀・金山泰雄・関口明浩, 省エネ型都市交通システム「エコライド」の振動乗り 心地に関する研究，第 11 回運動と振動の制御シンポジ ウム講演論文集， $(2009) ， 375-379$.

(5) 平沢隆之·須田義大・音羽勇哉・竹原昭一郎・表 久紀, 快適性モデリングを通じた省エネ小型公共交通の車内 空間デザインに関する基礎検討，Dynamics and Design Conference 2010 にて発表予定. 